\title{
Human papillomavirus infection and ocular surface disease (Review)
}

\author{
AIKATERINI K. CHALKIA ${ }^{1}$, GEORGIOS BONTZOS ${ }^{2}$, \\ DEMETRIOS A. SPANDIDOS ${ }^{3}$ and EFSTATHIOS T. DETORAKIS ${ }^{1}$
}

\author{
${ }^{1}$ Department of Ophthalmology, University Hospital of Heraklion, 71110 Heraklion; ${ }^{2}$ Department of Ophthalmology, \\ Red Cross Hospital, 11526 Athens; ${ }^{3}$ Department of Virology, Medical School, University of Crete, 71110 Heraklion, Greece
}

Received February 20, 2019; Accepted March 15, 2019

DOI: $10.3892 /$ ijo.2019.4755

\begin{abstract}
Human papillomavirus (HPV) infection has been implicated as a primary cause of lesions in the anogenital region, skin, oropharynx and respiratory tract. Additionally, the role of HPV in the pathogenesis of ocular surface disease has also been extensively studied. Conjunctival papilloma development has been strongly associated with the HPV infection of certain subtypes. On the other hand, the role of HPV in conjunctival pterygium, conjunctival intraepithelial neoplasia (CIN) and ocular surface squamous neoplasia (OSSN) remains controversial. Genetic predisposition and environmental factor is important in HPV hosts as regards the pathogenesis of ocular surface disease. Several studies have indicate a synergic role of HPV with ultraviolet radiation in pterygium establishment. A higher recurrence risk rate and more aggressive disease of ophthalmic pterygium is observed in cases of HPV infection. The purpose of this review was to provide a systematic review of the literature and to assist in a better understanding of the role of HPV in ocular surface disease.
\end{abstract}

\section{Contents}

1. Introduction

2. Data collection methods

3. HPV detection in ophthalmic pterygium

Correspondence to: Dr Efstathios T. Detorakis, Department of Ophthalmology, University Hospital of Heraklion, 71110 Heraklion, Greece

E-mail: detorakis@hotmail.com

Abbreviations: HPV, human papillomavirus; CIN, conjunctival intraepithelial neoplasia; OSSN, ocular surface squamous neoplasia; SCCC, squamous cell carcinoma of the conjuctiva; UV, ultraviolet; MMC, mitomycin C; EV, Epidermodysplasia verruciformis

Key words: human papillomavirus, virus, conjunctiva, papilloma, neoplasia
4. HPV detection in conjunctival papilloma

5. HPV detection in ocular surface squamous neoplasia

6. Conclusions and future perspectives

\section{Introduction}

Papillomaviruses (HPV) belong to the virus family of Papovaviridae. The papillomaviruses are highly host species-specific and tissue-restricted, and present epithelial tropism. More than 100 genotypes of human papillomaviruses have been fully sequenced, and more HPV types are continuously being found $(1,2)$.

All recognized viruses require terminal differentiation for replication and virion production. HPVs cause a wide range of diseases from benign lesions to invasive tumors (3). They are grouped in 3 groups as follows: Cutaneous, mucocutaneous and associated with the autosomal recessive epidermodysplasia verruciformis $(\mathrm{EV})$. According to their propensity for malignant progression in the cervix, mucocutaneous HPVs have been divided into low- and high-risk types (4).

Papillomaviruses are small, non-enveloped viruses with icosahedral symmetry and contain a double-strained circular DNA with approximately 8 open reading frames which are divided into 3 functional regions: The early $(E)$ region encoding proteins E1- E7 responsible for viral replication, the late $(\mathrm{L})$ region encoding structural proteins L1-L2, and the long control region (LCR) responsible for transcription and replication $(5,6)$. Only the E6 and E7 proteins of high-risk HPV strains present transforming properties by interacting with the tumor suppressor genes p53 and with the retinoblastoma family of proteins $\mathrm{pRb}$, involved in controlling cell proliferation $(7,8)$. The viral proteins may also contribute to potentially higher number of abnormalities in the cell genetic material (9).

In recent years, HPV has been associated with benign and malignant lesions of not only the anogenital region, but also of the skin, oropharynx, respiratory tract and ocular surface with variation of different genotypes tropism in the various anatomical sites (10-12). The epithelium of the ocular surface is exposed to the environment and therefore it is susceptible to infections, particularly in cases when protective barriers of mucin, tears and superficial cellular layer are compromised. HPV has mainly been shown to be involved in the pathogenesis 
of ocular surface diseases, such as conjunctival papillomas, papillomas and carcinomas of the lacrimal sac, conjunctival intraepithelial neoplasia (CIN), ocular surface squamous neoplasia (OSSN) and conjunctival pterygium and even squamous cell carcinoma of the conjunctiva (SCCC) (12-14).

\section{Data collection methods}

For this review article, a thorough search on MEDLINE (through PubMed), EMBASE (through OVID) and SCOPUS was performed, from inception to February, 2019, in order to identify studies addressing the association between infection with HPV and ocular surface disease.

\section{HPV detection in ophthalmic pterygium}

Conjunctival pterygia are fibrovascular lesions of the bulbar conjunctiva, that can display an aggressive clinical behavior and, occasionally, threaten vision. They represent a proliferative disorder of the conjunctiva, characterized by the overgrowth of altered limbal cells centripetally towards the cornea in a wing-shaped manner. In advanced stages, they present Bowman's layer dissolution, epithelial and mesenchymal transition and stromal inflammation, neovascularization and matrix remodeling under the action of cytokines, growth factors matrix metalloproteinases and vascular endothelial growth factors. They have a predilection for nasal limbus and their growth can obscure the visual axis, and can cause irregular astigmatism and chronic inflammation (15). Its pathogenesis is considered a multifactorial process where ultraviolet (UV) radiation (16) and other environmental factors, genetic predisposition and oncogenic viruses may play a role (17). Increased UV-associated oxidative stress has been reported in pterygium, compared with normal conjunctiva, leading to the induction of proteins, such as survivin (18). The latter has been associated with DNA oxidation and the downregulation of p53 (18). Detorakis et al (19) previously identified potential viral co-morbidity in pterygium development and proposed a 'two-hit' theory for its establishment. The first hit is a damaging reaction mediated by UV radiation exposure that leads to genetic alterations or mutations, and the second hit is an oncogenic event mediated by viral infection in the compromised ocular barriers.

HPV has been extensively studied as a possible pathogenetic co-factor; however controversy exists between different studies (Table I). In their studies, McDonnell et al (20), Dushku et al (22), Chen et al (26), Schellini et al (28), Kuo et al (29), Otlu et al (32), Guthoff et al (34) and Hamed-Azzam et al (38) did not detect HPV in pterygia, while Sjo et al (13), Takamura et al (30) and Hsaio et al (36) noted a very low prevalence of the virus ranging from $3-4,8 \%$.

On the contrary, a number of previously published studies have successfully detected HPV $(21,23-25,27,31,33,35,37,39)$ The average HPV prevalence in human pterygium was found to be $18.6 \%$ (range $0-100 \%$ ) (40). The lack of consensus between studies could reflect differences in methodology and sampling. Piras et al (25) proposed that geographic differences in the prevalence of the virus in the various countries may explain these findings, supporting its multifactorial pathogenesis.
The diagnosis of viral infection is based on the detection of HPV-DNA. The application of various detection techniques with varied sensitivity and specificity can significantly compromise the results (41). HPV-DNA can be directly isolated from a biopsy specimen with in situ hybridization (ISH), Southern blotting and dot blot hybridization. These techniques however, are laborious and lack sensitivity. By contrast, polymerase chain reaction (PCR) is highly associated with false-positive results due to its high sensitivity (42). Real-time PCR permits the rapid detection and quantification of the viral load (42). Reverse transcriptase-PCR is a qualitative assay that permits the identification of viral gene expression with the use of reverse transcriptase (42). A combination of the previous techniques can be applied in order to acquire qualitative and qualitative information of viral gene expression.

Pterygium treatment is based on surgical excision and the topical use of antimetabolites, such as mitomycin C (MMC) or 5-fluorouracil. Several surgical techniques have been described, such as bare sclera closure and sliding conjunctival flaps (43). The additional use of conjunctival autografts or amniotic membrane grafts, has significantly lowered the need for repetitive surgery, although recurrences may still occur (44).

\section{HPV detection in conjunctival papilloma}

Conjunctival papillomas represent one of the most common benign tumors of the squamous epithelium of the conjunctiva. They may display dysplasia, but rarely undergo malignant transformation (45). Despite their tendency to recur following surgical excision, spontaneous regression is possible. According to their growth pattern, conjunctival papillomas may present as exophytic, mixed or more rarely inverted. The exophytic growth pattern may be sessile or pedunculated (12). Although they can appear in both children and adults (46), they most frequently occur in adults aged 20-39 years, which also corresponds to the peak age of genital HPV infection in sexually active adults. Papillomas seem to appear with a male preponderance and their incidence declines with increasing age. They are usually detected medially and inferiorly on the conjunctiva (45).

Their pathogenetic role has not been fully clarified. HPV infection by auto-inoculation from contaminated fingers has been strongly associated with their development. Fetal passage through an HPV-infected birth canal may explain the presence of conjunctival papilloma in children. Several studies have investigated the role of HPV in the pathogenesis of conjunctival papilloma (Table II). In the majority of these cases, the low-risk HPV types 6 and 11, typically found in condylomata accuminata, are predominant among HPV-infected conjunctival papillomas with an incidence varying from 50-100\%. Egbert and Kersten (61) also refer the detection of HPV 6 and 11 in a conjunctival papilloma of an infant whose mother suffered from vulvar HPV infection during pregnancy, indicating a possible vertical transmission during delivery. The detection of low-risk HPV types in conjunctival papillomas may explain the benign nature of these lesions. In addition, HPV infection has been also detected in epithelial lacrimal sac papillomas and carcinomas. The tear 
Table I. HPV in ophthalmic pterygium.

\begin{tabular}{|c|c|c|c|c|c|c|}
\hline Author (Refs.) & $\begin{array}{c}\text { Date of } \\
\text { publication }\end{array}$ & $\begin{array}{c}\text { HPV } \\
\text { prevalence }\end{array}$ & $\begin{array}{l}\text { HPV } \\
\text { type }\end{array}$ & $\begin{array}{l}\text { Country of } \\
\text { the study }\end{array}$ & $\begin{array}{l}\text { Method of } \\
\text { detection }\end{array}$ & $\begin{array}{c}\text { Sample } \\
\text { size }\end{array}$ \\
\hline McDonell et al (20) & 1992 & $0 \%$ & - & USA & PCR & 6 \\
\hline Varinli et al (21) & 1994 & $64 \%$ & - & Turkey & IHC & 25 \\
\hline Dushku et al (22) & 1999 & $0 \%$ & - & USA & PCR & 13 \\
\hline Detorakis et al (23) & 2001 & $24 \%$ & 18 & Greece & PCR & 50 \\
\hline Gallagher et al (24) & 2001 & $50 \%$ & $6,11,16$ & UK & PCR & 10 \\
\hline Piras et al (25) & 2003 & $\begin{array}{l}100 \% \\
21 \%\end{array}$ & $\begin{array}{l}\text { Types 52, 54, } \\
\text { candHPV90 }\end{array}$ & $\begin{array}{l}\text { Italy/ } \\
\text { Equador }\end{array}$ & $\begin{array}{l}\text { PCR, } \\
\text { sequencing }\end{array}$ & 41 \\
\hline Chen et al (26) & 2003 & $0 \%$ & - & Taiwan & PCR & 65 \\
\hline Ateenyi-Agaba et al (27) & 2004 & $50 \%$ & 11,37 & Uganda & PCR, Southern blotting & 10 \\
\hline Schellini et al (28) & 2006 & $0 \%$ & - & Brazil & PCR & 36 \\
\hline Kuo et al (29) & 2006 & $0 \%$ & - & Taiwan & PCR & 4 \\
\hline Sjö et al (13) & 2007 & $4.4 \%$ & 6 & Denmark & PCR, ISH & 90 \\
\hline Takamura et al (30) & 2008 & $4.8 \%$ & - & Japan & PCR-HC II & 42 \\
\hline Rodrigues et al (31) & 2008 & $58.3 \%$ & $1,2,16$ & Brazil & PCR & 36 \\
\hline Otlu et al (32) & 2009 & $0 \%$ & - & Turkey & Real-time PCR & 40 \\
\hline Tsai et al (33) & 2009 & $24 \%$ & 16,18 & Taiwan & Nested PCR & 129 \\
\hline Guthoff et al (34) & 2009 & $0 \%$ & - & Germany & PCR, IHC & \\
\hline Piecyk-Sidor et al (35) & 2009 & $27.6 \%$ & $\begin{array}{c}5,6,11,16, \\
18,31,52,59\end{array}$ & Poland & PCR & 58 \\
\hline Hsiao et al (36) & 2010 & $3 \%$ & 18 & Taiwan & PCR, ISH & 65 \\
\hline Chong et al (37) & 2014 & $64.4 \%$ & $16,18,58,59$ & Malaysia & Nested PCR & 45 \\
\hline Hamed-Azzam et al (38) & 2016 & $0 \%$ & - & Israel & IHC & 100 \\
\hline Chalkia et al (39) & 2018 & $42.86 \%$ & $33,39,45,56,59,66$ & Greece & Real-time PCR & 21 \\
\hline
\end{tabular}

HPV, human papillomavirus; IHC, immunohistochemistry; ISH, in situ hybridization; HC II, hybrid capture II.

flow on an HPV infected conjunctiva may be responsible for the development of such lesions.

Treatment options of conjunctival papillomas include mainly surgical excision, cryotherapy and carbon dioxide laser (62). Additionally, oral cimetidine, topical MMC and topical interferon- $\alpha$ have been implicated in the management of these benign lesions (63). However, despite the various therapies, the recurrence rate in conjunctival papilloma remains high (6-27\%).

\section{HPV detection in ocular surface squamous neoplasia}

OSSN encompasses a wide range of conjunctival lesions that range histologically from dysplasia and carcinoma in situ, generally termed CIN, to invasive SCCC and is considered the most common ocular-surface malignancy (64). It involves more commonly the interpalpebral area, arising from the limbus and may extend to involve cornea (65). The incidence of OSSN varies widely with increased incidence in countries where HIV infection is an epidemic (66). In fact, immunosuppression due to HIV-infection has been strongly associasted with OSSN, as various studies have demonstrated a 10 -fold increase for OSSN in these patients. Other risk factors associated with OSSN are an advanced age, the male sex, UV exposure, immunosuppression, atopic eczema and xeroderma pigmentosum $(66,67)$. Conjunctival SCC represents the most severe form of OSSN, which if left untreated, can result in mortality (68). Metastasis to lymph nodes is common; thus, aggressive treatment with enucleation or exenteration should be considered (69).

A number of studies have been conducted in order to identify the presence of HPV in OSSN (Table III). However, the reported presence of the virus varies widely with a range from $0-100 \%$. From the studies reported to date in Table III, an average prevalence rate of $33.8 \%$ (range, $0-100 \%$ ) has been observed. It should also be noted that in the majority of these studies, the HIV status of the patients has not been disclosed, leaving the role of HIV as enhancer or confounder of HPV carcinogenicity in OSSN unclear. In a number of studies, mucosal, mainly high risk types 16 and 18 have been detected. Scott et al (75) isolated HPV16 and mRNA corresponding to the E6 region in CIN specimens. Notably, Ateenyi-Agaba et al (14) detected cutaneous HPV types in nearly half of OSSN cases in HIV-positive patients, but rarely in HIV-negative patients, and thus no association was found with mucosal types in both groups. 
Table II. HPV in conjuctival papilloma.

\begin{tabular}{|c|c|c|c|c|c|}
\hline Author (Refs.) & Date of publication & HPV prevalence & HPV types & Method of detection & Sample size \\
\hline Lass et al (47) & 1983 & $50 \%$ & 11 & SB & 2 \\
\hline Naghashfar et al (48) & 1986 & $0 \%$ & - & SB/ISH & 1 \\
\hline McDonnell et al (49) & 1987 & $65 \%$ & 6,11 & ISH & 23 \\
\hline Mäntyjärvi et al (50) & 1989 & $0 \%$ & - & ISH & 1 \\
\hline Fierlbeck et al (51) & 1990 & $0 \%$ & - & ISH & 1 \\
\hline Mincione et al (52) & 1992 & $50 \%$ & 6,11 & ISH & 4 \\
\hline Saegusa et al (53) & 1995 & $100 \%$ & 16 & PCR & 5 \\
\hline Michel et al (54) & 1996 & $0 \%$ & - & ISH & 1 \\
\hline Nakamura et al (55) & 1997 & $50 \%$ & 6 & PCR & 8 \\
\hline Assadoullina et al (56) & 2000 & $0 \%$ & - & PCR & 1 \\
\hline Sjo et al (57) & 2001 & $92 \%$ & $6,11,16$ & PCR & 52 \\
\hline Minchiotti et al (58) & 2006 & $100 \%$ & 11 & PCR & 4 \\
\hline Sjö et al (59) & 2007 & $81 \%$ & $6,11,45$ & PCR & 106 \\
\hline Takamura et al (30) & 2008 & $100 \%$ & - & PCR/HC-II & 8 \\
\hline Annadanam et al (60) & 2017 & $100 \%$ & 6,11 & ISH & 1 \\
\hline
\end{tabular}

HPV, human papillomavirus; SB, Southern blotting; ISH, in situ hybridization; HC II, hybrid capture II.

Chauhan et al (84) also reported an improved disease-free survival of patients with HPV-infected OSSN. On the other hand, De Koning et al (81) noted a low prevalence of cutaneous HPV cases and no evidence of association of mucosal HPV types with OSSN. Tornesello et al (79) also noted an absence of high-risk types and low detection of EV-related types in their study and yet, another study (74) did not note significant correlation between abnormal p53 gene-product expression in OSSN and HPV infection. These discrepancies between the different studies render the role of HPV in OSSN uncertain.

Margin-free excision remains the treatment of choice for OSSN. The additional use of topical mitomycin, 5-fluorouracil, interferon and cryotherapy and radiation may be used to reduce the risk of recurrence and metastasis (87).

\section{Conclusions and future perspectives}

HPV is a known cause of intraepithelial damage which leads to squamous neoplasms on mucosal surfaces (88). Many types of cervical carcinoma and precancerous lesions have been attributed to HPV infection. In addition, HPV has been linked with dysplastic and malignant squamous lesions of the oropharynx (89). The associatoin between HPV and squamous neoplasms of the ocular surface and the conjunctiva is not completely understood. It appears that the HPV genotype as well as the presence of associated risk factors play a significant role in lesion pathogenesis $(13,45)$.

Koilocytosis is the histological hallmark of HPV infection (90). The koilocyte is a superficial or intermediate mature squamous cell characterized by perinuclear vacuolation, densely staining peripheral cytoplasm, and a nucleus with an undulating nuclear membrane and a rope-like chromatin pattern (91). Viral antigen has been demonstrated in nuclei of koilocytes using broad spectrum papillomavirus antibodies (47).

HPV has been identified in several lesions of the ocular surface. A strong association between HPV types 6 and 11 and conjunctival papilloma has been established $(49,52,57,59,60)$. The varied percentages of papillomas associated with HPV presence could be attributed to differences in genetic predisposition, lifestyle and environmental exposure (73). In cases of pterygium, the association between the virus presence is not clear. Based on current data, HPV appears to function as a pathogenetic co-factor in addition to genetic factors like p53 gene mutation (92), as well as environmental factors, such as UV radiation and HIV co-infection (18) and chemical exposure (73). Despite the controversies in the literature, HPV infections seem to be a crucial co-morbidity in susceptible hosts (33). Frequent recurrences of a pterygium following excision may be associated with the presence of HPV (24). The proposed pathogenesis involves p53 inactivation (33).

While there is a strong association between HIV and the risk of OSSN (66), the role of HPV is less conclusive. Previous studies have suggested that only the cutaneous HPV subtype, and not the mucosal, is correlated with the presence of OSSN $(14,81)$. Furthermore, older individuals seem to be more prone to the development of the described lesions (40).

The discrepancies in the reported results may be attributed to the selection bias of different regions (25) and the different methods for HPV isolation. While there is no gold standard for measuring HPV, PCR is generally considered to be the most sensitive method (76). It should also be noted that the newer HPV subtypes are continuously sequenced; thus, the range of possible genotype identification is incomplete. Some unknown types of HPV could be involved in the pterygium pathogenesis (93). Chalkia et al (39) described PCR-mediated 
Table III. HPV in OSSN

\begin{tabular}{|c|c|c|c|c|c|c|}
\hline Author (Refs.) & $\begin{array}{c}\text { Date of } \\
\text { publication }\end{array}$ & $\begin{array}{c}\text { HPV } \\
\text { prevalence }\end{array}$ & $\begin{array}{l}\text { HPV } \\
\text { types }\end{array}$ & $\begin{array}{l}\text { Method of } \\
\text { detection }\end{array}$ & $\begin{array}{l}\text { Sample } \\
\text { size }\end{array}$ & $\begin{array}{l}\text { HIV } \\
\text { status }\end{array}$ \\
\hline Lauer et al (70) & 1990 & $80 \%$ & 16,18 & PCR & 5 & - \\
\hline Tuppurainen et al (71) & 1992 & $0 \%$ & - & $\mathrm{PCR} / \mathrm{ISH}$ & 4 & - \\
\hline McDonnell et al (20) & 1992 & $88 \%$ & 16 & PCR & 42 & - \\
\hline Tabrizi et al (72) & 1997 & $39 \%$ & $6,11,16,18$ & PCR & 88 & - \\
\hline Karcioglu et al (73) & 1997 & $55.6 \%$ & 16,18 & Nested PCR, SB & 45 & - \\
\hline Dushku et al (22) & 1999 & 0 & - & Nested PCR & 8 & - \\
\hline Toth et al (74) & 2000 & $22 \%$ & 16,18 & PCR/IHC & 23 & - \\
\hline Scott et al (75) & 2002 & $100 \%$ & 16,18 & PCR/ISH & 10 & - \\
\hline Eng et al (76) & 2002 & $0 \%$ & - & Nested PCR & 20 & - \\
\hline Tulvatana et al (77) & 2003 & $0 \%$ & - & $\begin{array}{l}\text { PCR/dot } \\
\text { hybridization }\end{array}$ & 30 & - \\
\hline Ateenyi-Agaba et al (27) & 2004 & $86 \%$ & EV-HPV types & PCR & 21 & - \\
\hline Moubayed et al (78) & 2004 & $93 \%$ & $6,11,18$ & ISH immunomax & 14 & $64,2 \%$ \\
\hline Tornesello et al (79) & 2006 & $19.8 \%$ & $\begin{array}{c}\text { 6, 18, EV-related } \\
\text { HPVs, CJ198 }\end{array}$ & PCR & 86 & $\begin{array}{c}65,1 \% \\
\left(25 \% \mathrm{HPV}^{+}\right)\end{array}$ \\
\hline Kuo et al (29) & 2006 & $100 \%$ & $\begin{array}{c}6,11,16,18 \\
33,37,58,72\end{array}$ & Nested PCR & 9 & - \\
\hline Sen et al (80) & 2007 & $0 \%$ & - & $\mathrm{IHC}$ & 30 & - \\
\hline De Koning et al (81) & 2008 & & $\begin{array}{l}38 \% \text { Genital (both } \\
\text { high and low risk). } \\
22 \% \text { cutaneous types }\end{array}$ & PCR & 81 & $\left(48 \% \mathrm{HPV}^{+}\right)$ \\
\hline Manderwad et al (82) & 2009 & $0 \%$ & - & PCR/ISH-CARD & 57 & - \\
\hline Guthoff et al (34) & 2009 & $0 \%$ & - & $\mathrm{PCR} / \mathrm{IHC}$ & 31 & $\begin{array}{l}\text { No HIV } \\
\text { patients }\end{array}$ \\
\hline Ateenyi-Agaba et al (14) & 2010 & & $\begin{array}{c}\text { Mucosal HPV: } \\
\text { 6,4\% SCC; 7,7\% dysplasia } \\
\text { cutaneous HPV: } \\
\text { 44,7\% SCC; 41\% dysplasia }\end{array}$ & PCR & $\begin{array}{c}94 \text { SCC } \\
39 \text { dysplasia }\end{array}$ & $\begin{array}{l}\text { Uncertain } \\
\text { role of HIV }\end{array}$ \\
\hline Asadi-Amoli et al (83) & 2011 & $88 \%$ & No type found & Nested PCR & 50 & - \\
\hline Chauhan et al (84) & 2012 & $11 \%$ & 16 & PCR & 64 & - \\
\hline Woods et al (85) & 2013 & $6.5 \%$ & 16 & Nested PCR & 50 & - \\
\hline Afrogheh et al (86) & 2016 & $30 \%$ & 16 & IHC, ISH, PCR & 43 & $?$ \\
\hline
\end{tabular}

HPV, human papillomavirus; OSSN, ocular surface squamous neoplasia; ISH, in situ hybridization; CARD, catalyzed reporter deposition; IHC, immunohistochemistry; SCC, squamous cell carcinoma.

exfoliative cytology as a valuable detection method for HPV in ophthalmic pterygium, while others have used exfoliative cytology for OSSN and conjunctival papilloma (94). The use of an easy-applicable, reliable and cost effective method may offer a more detailed investigation of the role of HPV in ocular surface, that may permit the use of topical antiviral treatment in HPV related ocular surface diseases. In fact, two recent studies $(95,96)$ refer the efficient topical use of Cidofovir in OSSN. Cidofovir is a nucleoside analog with activity against a broad spectrum of DNA viruses. It has been used efficiently in squamous papilloma of the oropharynx, condylomata acuminata, molluscum contagiosum, and Kaposi's sarcoma $(97,98)$. Finally, it would be of interest to evaluate the potential effect of HPV vaccination on the prevalence of these diseases in the future.

To conclude, HPV infection seems to play an important role in several aspects of ocular surface disease. Further research is required to elucidate the specific pathogenetic mechanisms of HPV in various ocular surface disease entities and findings may be clinically important in view of the potential development of targeted therapies or preventive measures, such as HPV vaccines.

\section{Acknowledgements}

Not applicable. 


\section{Funding}

No funding was received.

\section{Availability of data and materials}

Not applicable.

\section{Authors' contributions}

AKC was involved in the design of the study, and in the acquisition of data, drafting and writing of the manuscript. GB was involved in the acquisition and analysis of the data from studies to be included in this review, and in the drafting and writing of the manuscript. ETD and DAS were involved in the conception of the study, and in the revision of the manuscript. All authors have read and approved the final version.

\section{Ethics approval and consent to participate}

Not applicable.

\section{Patient consent for publication}

Not applicable.

\section{Competing interests}

DAS is the Editor-in-Chief for the journal, but had no personal involvement in the reviewing process, or any influence in terms of adjudicating on the final decision, for this article. The other authors declare that they have no competing interests.

\section{References}

1. Bottalico D, Chen Z, Dunne A, Ostoloza J, McKinney S, Sun C, Schlecht NF, Fatahzadeh M, Herrero R, Schiffman M, et al: The oral cavity contains abundant known and novel human papillomaviruses from the Betapapillomavirus and Gammapapillomavirus genera. J Infect Dis 204: 787-792, 2011.

2. Köhler A, Gottschling M, Manning K, Lehmann MD, Schulz E, Krüger-Corcoran D, Stockfleth E and Nindl I: Genomic characterization of ten novel cutaneous human papillomaviruses from keratotic lesions of immunosuppressed patients. J Gen Virol 92 1585-1594, 2011

3. Duensing S and Münger K: Mechanisms of genomic instability in human cancer: Insights from studies with human papillomavirus oncoproteins. Int J Cancer 109: 157-162, 2004.

4. Cubie HA: Diseases associated with human papillomavirus infection. Virology 445: 21-34, 2013.

5. Mistry N, Wibom C and Evander M: Cutaneous and mucosal human papillomaviruses differ in net surface charge, potential impact on tropism. Virol J 5: 118, 2008.

6. Graham SV: Human papillomavirus: Gene expression, regulation and prospects for novel diagnostic methods and antiviral therapies. Future Microbiol 5: 1493-1506, 2010.

7. Zheng ZM and Baker CC: Papillomavirus genome structure, expression, and post-transcriptional regulation. Front Biosci 11 2286-2302, 2006

8. Münger K, Baldwin A, Edwards KM, Hayakawa H, Nguyen CL, Owens M, Grace M and Huh K: Mechanisms of human papillomavirus-induced oncogenesis. J Virol 78: 11451-11460, 2004.

9. Nair S and Pillai MR: Human papillomavirus and disease mechanisms: Relevance to oral and cervical cancers. Oral Dis 11: 350-359, 2005.
10. Ljubojevic S and Skerlev M: HPV-associated diseases. Clin Dermatol 32: 227-234, 2014.

11. Gélinas JF, Manoukian J and Côté A: Lung involvement in juvenile onset recurrent respiratory papillomatosis: A systematic review of the literature. Int J Pediatr Otorhinolaryngol 72: 433-452, 2008.

12. Verma V, Shen D, Sieving PC and Chan CC: The role of infectious agents in the etiology of ocular adnexal neoplasia. Surv Ophthalmol 53: 312-331, 2008

13. Sjö NC, von Buchwald C, Prause JU, Norrild B, Vinding T and Heegaard S: Human papillomavirus and pterygium. Is the virus a risk factor? Br J Ophthalmol 91: 1016-1018, 2007.

14. Ateenyi-Agaba C, Franceschi S, Wabwire-Mangen F, Arslan A, Othieno E, Binta-Kahwa J, van Doorn LJ, Kleter B, Quint W and Weiderpass E: Human papillomavirus infection and squamous cell carcinoma of the conjunctiva. Br J Cancer 102: 262-267, 2010.

15. Hilgers JH: Pterygium: Its incidence, heredity and etiology. Am J Ophthalmol 50: 635-644, 1960.

16. Zhou WP, Zhu YF, Zhang B, Qiu WY and Yao YF: The role of ultraviolet radiation in the pathogenesis of pterygia (Review). Mol Med Rep 14: 3-15, 2016.

17. Cárdenas-Cantú E, Zavala J, Valenzuela J and Valdez-García JE: Molecular basis of pterygium development. Semin Ophthalmol 31: 567-583, 2016.

18. Maxia C, Perra MT, Demurtas P, Minerba L, Murtas D, Piras F, Corbu A, Gotuzzo DC, Cabrera RG, Ribatti D, et al: Expression of survivin protein in pterygium and relationship with oxidative DNA damage. J Cell Mol Med 12: 2372-2380, 2008.

19. Detorakis ET, Drakonaki EE and Spandidos DA: Molecular genetic alterations and viral presence in ophthalmic pterygium. Int J Mol Med 6: 35-41, 2000.

20. McDonnell JM, McDonnell PJ and Sun YY: Human papillomavirus DNA in tissues and ocular surface swabs of patients with conjunctival epithelial neoplasia. Invest Ophthalmol Vis Sci 33: 184-189, 1992.

21. Varinli S, Varinli I, Köksal Erkisi M and Doran F: Human papillomavirus in pterygium. Cent Afr J Med 40: 24-26, 1994.

22. Dushku N, Hatcher SL, Albert DM and Reid TW: p53 expression and relation to human papillomavirus infection in pingueculae, pterygia, and limbal tumors. Arch Ophthalmol 117: 1593-1599, 1999.

23. Detorakis ET, Sourvinos G and Spandidos DA: Detection of herpes simplex virus and human papilloma virus in ophthalmic pterygium. Cornea 20: 164-167, 2001.

24. Gallagher MJ, Giannoudis A, Herrington CS and Hiscott P: Human papillomavirus in pterygium. Br J Ophthalmol 85: 782-784, 2001.

25. Piras F, Moore PS, Ugalde J, Perra MT, Scarpa A and Sirigu P: Detection of human papillomavirus DNA in pterygia from different geographical regions. Br J Ophthalmol 87: 864-866, 2003.

26. Chen KH, Hsu WM, Cheng CC and Li YS: Lack of human papillomavirus in pterygium of Chinese patients from Taiwan. Br J Ophthalmol 87: 1046-1048, 2003.

27. Ateenyi-Agaba C, Weiderpass E, Smet A, Dong W, Dai M, Kahwa B, Wabinga H, Katongole-Mbidde E, Franceschi S and Tommasino M: Epidermodysplasia verruciformis human papillomavirus types and carcinoma of the conjunctiva: A pilot study. Br J Cancer 90: 1777-1779, 2004.

28. Schellini SA, Hoyama E, Shiratori CA, Sakamoto RH and Candeias JM: Lack of papillomavirus (HPV) in pterygia of a Brazilian sample. Arq Bras Oftalmol 69: 519-521, 2006.

29. Kuo KT, Chang HC, Hsiao CH and Lin MC: Increased Ki-67 proliferative index and absence of P16INK4 in CIN-HPV related pathogenic pathways different from cervical squamous intraepithelial lesion. Br J Ophthalmol 90: 894-899, 2006.

30. Takamura Y, Kubo E, Tsuzuki S and Akagi Y: Detection of human papillomavirus in pterygium and conjunctival papilloma by hybrid capture II and PCR assays. Eye (Lond) 22: 1442-1445, 2008.

31. Rodrigues FW, Arruda JT, Silva RE and Moura KK: TP53 gene expression, codon 72 polymorphism and human papillomavirus DNA associated with pterygium. Genet Mol Res 7: 1251-1258, 2008.

32. Otlu B, Emre S, Turkcuoglu P, Doganay S and Durmaz R: Investigation of human papillomavirus and Epstein-Barr virus DNAs in pterygium tissue. Eur J Ophthalmol 19: 175-179, 2009.

33. Tsai YY, Chang CC, Chiang CC, Yeh KT, Chen PL, Chang CH, Chou MC, Lee H and Cheng YW: HPV infection and p53 inactivation in pterygium. Mol Vis 15: 1092-1097, 2009. 
34. Guthoff R, Marx A and Stroebel P: No evidence for a pathogenic role of human papillomavirus infection in ocular surface squamous neoplasia in Germany. Curr Eye Res 34: 666-671, 2009.

35. Piecyk-Sidor M, Polz-Dacewicz M,Zagórski Z and Zarnowski T: Occurrence of human papillomavirus in pterygia. Acta Ophthalmol 87: 890-895, 2009

36. Hsiao CH, Lee BH, Ngan KW, Chuang WY, Yeung L, Yeh LK, Tan HY, Hui-Kang D and Lin KK: Presence of human papillomavirus in pterygium in Taiwan. Cornea 29: 123-127, 2010.

37. Chong PP, Tung CH, Rahman NA, Yajima M, Chin FW, Yeng CL, Go ES, Chan CM, Yawata N and Yamamoto N: Prevalence and viral load of oncogenic human papillomavirus (HPV) in pterygia in multi-ethnic patients in the Malay Peninsula. Acta Ophthalmol 92: e569-e579, 2014.

38. Hamed-Azzam S, Edison N, Briscoe D, Mukari A and Elmalah I Identification of human papillomavirus in pterygium. Acta Ophthalmol 94: e195-e197, 2016.

39. Chalkia AK, Derdas S, Bontzos G, Sourvinos G and Detorakis ET: Non-invasive detection of HPV DNA in exfoliative samples from ophthalmic pterygium: A feasibility study. Graefes Arch Clin Exp Ophthalmol 256: 193-198, 2018.

40. Di Girolamo N: Association of human papilloma virus with pterygia and ocular-surface squamous neoplasia. Eye (Lond) 26 202-211, 2012

41. Abreu AL, Souza RP, Gimenes F and Consolaro ME: A review of methods for detect human Papillomavirus infection. Virol J 9 : $262,2012$.

42. Mackay IM: Real-time PCR in the microbiology laboratory. Clin Microbiol Infect 10: 190-212, 2004.

43. Hirst LW: The treatment of pterygium. Surv Ophthalmol 48 145-180, 2003

44. Todani A and Melki SA: Pterygium: Current concepts in pathogenesis and treatment. Int Ophthalmol Clin 49: 21-30, 2009.

45. Sjö N, Heegaard S and Prause JU: Conjunctival papilloma. A histopathologically based retrospective study. Acta Ophthalmol Scand 78: 663-666, 2000

46. Elsas FJ and Green WR: Epibulbar tumors in childhood. Am J Ophthalmol 79: 1001-1007, 1975

47. Lass JH, Jenson AB, Papale JJ and Albert DM: Papillomavirus in human conjunctival papillomas. Am J Ophthalmol 95: 364-368, 1983.

48. Naghashfar Z, McDonnell PJ, McDonnell JM, Green WR and Shah KV: Genital tract papillomavirus type 6 in recurrent conjunctival papilloma. Arch Ophthalmol 104: 1814-1815, 1986.

49. McDonnell PJ, McDonnell JM, Kessis T, Green WR and Shah KV: Detection of human papillomavirus type 6/11 DNA in conjunctival papillomas by in situ hybridization with radioactive probes. Hum Pathol 18: 1115-1119, 1987.

50. Mäntyjärvi M, Syrjänen S, Kaipiainen S, Mäntyjärvi R, Kahlos T and Syrjänen K: Detection of human papillomavirus type 11 DNA in a conjunctival squamous cell papilloma by in situ hybridization with biotinylated probes. Acta Ophthalmol (Copenh) 67: 425-429, 1989.

51. Fierlbeck G, Rassner G, Thiel HJ and Pfister H: Virus-induced papilloma of the conjunctiva. Detection of HPV 6a DNA. Z Hautkr 65: 497-499, 1990 (In German).

52. Mincione GP, Taddei GL, Wolovsky M, Calzolari A and Mincione F: Detection of human papillomavirus (HPV) DNA type 6/11 in a conjunctival papilloma by in situ hybridization with biotinylated probes. Pathologica 84: 483-488, 1992.

53. Saegusa M, Takano Y, Hashimura M, Okayasu I and Shiga J: HPV type 16 in conjunctival and junctional papilloma, dysplasia, and squamous cell carcinoma. J Clin Pathol 48 : 1106-1110, 1995.

54. Michel JL, Guiguen Y, Léger F, Gain P, Valanconny C and Cambazard F: Human papillomavirus $6 / 11$ in conjunctival papilloma. Ann Dermatol Venereol 123: 90-92, 1996 (In French).

55. Nakamura Y, Mashima Y, Kameyama K, Mukai M and Oguchi Y: Detection of human papillomavirus infection in squamous tumours of the conjunctiva and lacrimal sac by immunohistochemistry, in situ hybridisation, and polymerase chain reaction. Br J Ophthalmol 81: 308-313, 1997.

56. Assadoullina A, Bialasiewicz AA, de Villiers EM and Richard G: Detection of HPV-20, HPV-23, and HPV-DL332 in a solitary eyelid syringoma. Am J Ophthalmol 129: 99-101, 2000

57. Sjö NC, Heegaard S, Prause JU, von Buchwald C and Lindeberg $\mathrm{H}$ : Human papillomavirus in conjunctival papilloma. Br J Ophthalmol 85: 785-787, 2001.
58. Minchiotti S, Masucci L, Serapiao Dos Santos M, Perrella E, Graffeo R, Lambiase A and Bonini S: Conjunctival papilloma and human papillomavirus: Identification of HPV types by PCR. Eur J Ophthalmol 16: 473-477, 2006

59. Sjö NC, von Buchwald C, Cassonnet P, Norrild B, Prause JU, Vinding $\mathrm{T}$ and Heegaard S: Human papillomavirus in normal conjunctival tissue and in conjunctival papilloma: Types and frequencies in a large series. Br J Ophthalmol 91: 1014-1015, 2007.

60. Annadanam A, Vizcaino MA, Eberhart CG, Khurshid GS and Gupta P: Long standing exophytic conjunctival papilloma infected with human papillomavirus. J Eye Ophthalmol 4: 1, 2017.

61. Egbert JE and Kersten RC: Female genital tract papillomavirus in conjunctival papillomas of infancy. Am J Ophthalmol 123 551-552, 1997.

62. Kalogeropoulos C, Koumpoulis I, Papadiotis E, Zioga A, Gkrepi K, Pappa C, Paschides C, Malamou-Mitsi V and Aspiotis M: Squamous cell papilloma of the conjunctiva due to human papillomavirus (HPV): Presentation of two cases and review of literature. Clin Ophthalmol 6: 1553-1561, 2012.

63. Shields CL and Shields JA: Tumors of the conjunctiva and cornea. Surv Ophthalmol 49: 3-24, 2004.

64. Lee GA and Hirst LW: Ocular surface squamous neoplasia. Surv Ophthalmol 39: 429-450, 1995.

65. Lee GA and Hirst LW: Retrospective study of ocular surface squamous neoplasia. Aust N Z J Ophthalmol 25: 269-276, 1997.

66. Gichuhi S, Sagoo MS, Weiss HA and Burton MJ: Epidemiology of ocular surface squamous neoplasia in Africa. Trop Med Int Health 18: 1424-1443, 2013

67. Ahmed H, Hassan RY and Pindiga UH: Xeroderma pigmentosum in three consecutive siblings of a Nigerian family: Observations on oculocutaneous manifestations in black African children. Br J Ophthalmol 85: 110-111, 2001.

68. Ogun GO, Ogun OA, Bekibele CO and Akang EE: Intraepithelial and invasive squamous neoplasms of the conjunctiva in Ibadan, Nigeria: A clinicopathological study of 46 cases. Int Ophthalmol 29: 401-409, 2009.

69. McKelvie PA, Daniell M, McNab A, Loughnan M and Santamaria JD: Squamous cell carcinoma of the conjunctiva: A series of 26 cases. Br J Ophthalmol 86: 168-173, 2002.

70. Lauer SA, Malter JS and Meier JR: Human papillomavirus type 18 in conjunctival intraepithelial neoplasia. Am J Ophthalmol 110: 23-27, 1990

71. Tuppurainen K, Raninen A, Kosunen O, Kankkunen JP, Kellokoski J, Syrjänen S, Mäntyjärvi $M$ and Syrjänen $K$ : Squamous cell carcinoma of the conjunctiva. Failure to demonstrate HPV DNA by in situ hybridization and polymerase chain reaction. Acta Ophthalmol (Copenh) 70: 248-254, 1992.

72. Tabrizi SN, McCurrach FE, Drewe RH, Borg AJ, Garland SM and Taylor HR: Human papillomavirus in corneal and conjunctival carcinoma. Aust N Z J Ophthalmol 25: 211-215, 1997.

73. Karcioglu ZA and Issa TM: Human papilloma virus in neoplastic and non-neoplastic conditions of the external eye. Br J Ophthalmol 81: 595-598, 1997

74. Toth J, Karcioglu ZA, Moshfeghi AA, Issa TM, Al-Ma'ani JR and Patel KV: The relationship between human papillomavirus and p53 gene in conjunctival squamous cell carcinoma. Cornea 19: $159-162,2000$

75. Scott IU, Karp CL and Nuovo GJ: Human papillomavirus 16 and 18 expression in conjunctival intraepithelial neoplasia. Ophthalmology 109: 542-547, 2002.

76. Eng HL, Lin TM, Chen SY, Wu SM and Chen WJ: Failure to detect human papillomavirus DNA in malignant epithelial neoplasms of conjunctiva by polymerase chain reaction. Am J Clin Pathol 117: 429-436, 2002

77. Tulvatana W, Bhattarakosol P, Sansopha L, Sipiyarak W, Kowitdamrong E, Paisuntornsug T and Karnsawai S: Risk factors for conjunctival squamous cell neoplasia: A matched case-control study. Br J Ophthalmol 87: 396-398, 2003.

78. Moubayed P, Mwakyoma H and Schneider DT: High frequency of human papillomavirus $6 / 11,16$, and 18 infections in precancerous lesions and squamous cell carcinoma of the conjunctiva in subtropical Tanzania. Am J Clin Pathol 122: 938-943, 2004.

79. Tornesello ML, Duraturo ML, Waddell KM, Biryahwaho B, Downing R, Balinandi S, Lucas SB, Buonaguro L and Buonaguro FM: Evaluating the role of human papillomaviruses in conjunctival neoplasia. Br J Cancer 94: 446-449, 2006.

80. Sen S, Sharma A and Panda A: Immunohistochemical localization of human papilloma virus in conjunctival neoplasias: A retrospective study. Indian J Ophthalmol 55: 361-363, 2007. 
81. de Koning MN, Waddell K, Magyezi J, Purdie K, Proby C, Harwood C, Lucas S, Downing R, Quint WG and Newton R: Genital and cutaneous human papillomavirus (HPV) types in relation to conjunctival squamous cell neoplasia: A case-control study in Uganda. Infect Agent Cancer 3: 12, 2008

82. Manderwad GP, Kannabiran C, Honavar SG and Vemuganti GK: Lack of association of high-risk human papillomavirus in ocular surface squamous neoplasia in India. Arch Pathol Lab Med 133: 1246-1250, 2009.

83. Asadi-Amoli F, Heidari AB, Jahanzad I and Jabbarvand M: Detection of human papillomavirus in squamous cell carcinoma of conjunctiva by nested PCR: A case control study in Iran. Acta Med Iran 49: 707-714, 2011.

84. Chauhan S, Sen S, Sharma A, Dar L, Kashyap S, Kumar P, Bajaj MS and Tandon R: Human papillomavirus: A predictor of better survival in ocular surface squamous neoplasia patients. $\mathrm{Br}$ J Ophthalmol 96: 1517-1521, 2012.

85. Woods M, Chow S, Heng B, Glenn W, Whitaker N, Waring D, Iwasenko J, Rawlinson W, Coroneo MT, Wakefield D, et al: Detecting human papillomavirus in ocular surface diseases. Invest Ophthalmol Vis Sci 54: 8069-8078, 2013.

86. Afrogheh AH, Jakobiec FA, Hammon R, Grossniklaus HE, Rocco J, Lindeman NI, Sadow PM and Faquin WC: Evaluation for high-risk HPV in squamous cell carcinomas and precursor lesions arising in the conjunctiva and lacrimal sac. Am J Surg Pathol 40: 519-528, 2016.

87. Yin VT, Merritt HA, Sniegowski M and Esmaeli B: Eyelid and ocular surface carcinoma: Diagnosis and management. Clin Dermatol 33: 159-169, 2015.

88. Hoffmann M, Ihloff AS, Görögh T, Weise JB, Fazel A, Krams M, Rittgen W, Schwarz E and Kahn T: p16(INK4a) overexpression predicts translational active human papillomavirus infection in tonsillar cancer. Int J Cancer 127: 1595-1602, 2010.

89. Quiroga-Garza G, Zhou H, Mody DR, Schwartz MR and Ge Y: Unexpected high prevalence of HPV 90 infection in an underserved population: Is it really a low-risk genotype? Arch Pathol Lab Med 137: 1569-1573, 2013.
90. Koss LG: Cytologic and histologic manifestations of human papillomavirus infection of the uterine cervix. Cancer Detect Prev 14: 461-464, 1990.

91. Rosai J: Ackerman's Surgical Pathology. Rosai J (ed). Mosby, St. Louis, p1358, 1996.

92. Joanna R, Renata Z, Witold P, Małgorzata S, Bernaczyk P and Chyczewski L: The evaluation of human papillomavirus and p53 gene mutation in benign and malignant conjunctiva and eyelid lesions. Folia Histochem Cytobiol 48: 530-533, 2010.

93. Bernard HU: The clinical importance of the nomenclature, evolution and taxonomy of human papillomaviruses. J Clin Virol 32 (Suppl 1): S1-S6, 2005.

94. Kayat KV, Correa Dantas PE, Felberg S, Galvão MA and Saieg MA: Exfoliative cy tology in the diagnosis of ocular surface squamous neoplasms. Cornea 36: 127-130, 2017.

95. Ip MH and Coroneo MT: Treatment of previously refractory ocular surface squamous neoplasia with topical cidofovir. JAMA Ophthalmol 135: 500-502, 2017.

96. Ip MH, Robert George CR, Naing Z, Perlman EM, Rawlinson W and Coroneo MT: Topical cidofovir for treatment-refractory ocular surface squamous neoplasia. Ophthalmology 125: 617-619, 2018.

97. Bielamowicz S, Villagomez V, Stager SV and Wilson WR: Intralesional cidofovir therapy for laryngeal papilloma in an adult cohort. Laryngoscope 112: 696-699, 2002.

98. Little RF, Merced-Galindez F, Staskus K, Whitby D, Aoki Y, Humphrey R, Pluda JM, Marshall V, Walters M, Welles L, et al: A pilot study of cidofovir in patients with kaposi sarcoma. J Infect Dis 187: 149-153, 2003.

This work is licensed under a Creative Commons Attribution-NonCommercial-NoDerivatives 4.0 International (CC BY-NC-ND 4.0) License. 